\title{
Variables Impacting Students' Performance in Management Course
}

\author{
Gopaldas Pawan Kumar* \\ Associate Professor, David Memorial Institute of Management, Tarnaka, \\ Secunderabad - 500017, Telangana, India
}

\begin{abstract}
Education system in India is at a tipping point. A large number of institutions in higher education are churning out lakhs of students' every year with less number of them finding gainful employment. The scenario is same for engineering, pharmacy as well as management students'. The college culture is being impacted by internet and technology bringing in diversion and also new ways of learning methods. Presently, various avenues available for students' to study ranges from all-in-one study material and online courses to training institutes which are found to be more attractive than the regimented classroom teaching. A study is undertaken to find out the variables affecting the academic performance of students' in management courses in terms of Semester Grade Point Average (SGPA) scores. With the government plan to have better outcomes of the reimbursement scheme the study indirectly aims to find the variables that affect the academic performance to enable government to introduce better monitoring controls. The findings statistically show a strong and significant correlation of academic performance with gender and class attendance and are found to predict the performance outcome of the students'.
\end{abstract}

Keywords: Academic Performance, Class Attendance, Internet, Management Course, Reimbursement Scheme

\section{Introduction}

Management education is a preferred course by most of the students' for a faster and successful career growth. The prospects of getting a job are perceived to be higher if one obtains an MBA degree. With the opening of economy, management education received a boost with a number of educational institutions offering the course on a standalone basis or attached to an engineering college. In Telangana, there are 295 management (MBA) colleges with an intake of 31570 students' (2017-18) out of which 21 are government/university colleges and 274 are private un-aided colleges. Most of the colleges are located in Hyderabad (54 colleges) and Ranga Reddy (65 colleges) districts with an intake of 6465 and 6825 students' respectively (TSCHE, 2018). In fact, undivided Andhra Pradesh State had 813 colleges with an intake of 96,060 students'. One of the main attractions of students' is the fee reimbursement scheme which the state government has in place.

There have been a number of studies in many countries to understand the factors that impact the performance of a student in the exams, more so, in the underdeveloped 
countries which have been trying to improve the quality levels of their education system. Many researchers in underdeveloped countries have taken up the task of identifying the factors that drive the interest of the students' in getting better grades. Most of them looked at demographics and other parameters like gender, family income, attendance, educational qualifications of parents, government support and social environment as variables/predictors to understand their impact on the student academic performance.

At this point it is relevant to discuss few points regarding attendance, fee reimbursement and diversions of students' from academic pursuits due to growing popularity of social media. The university rule for attendance is that in a semester, the student must attend $75 \%$ of the total classes conducted for the course. A relaxation of $10 \%$ is given on medical grounds if it is supported by medical certificate and payment of condonation fee. Further, the state government has put in place a fee reimbursement scheme for backward classes, scheduled castes, scheduled tribes and students' whose parents' annual income is less than Rs. 2 lakhs to encourage and support them to improve their educational qualifications. Also, it may be noted that the admission to the management course is through ICET (Integrated Common Entrance Test) conducted by a state university with a quota of $80 \%$ designated as counseling seats and balance $20 \%$ is allocated as management quota to be filled in by NRI and other students' who have not written entrance test. The fee structure is usually higher for these seats and vary based on reputation of respective colleges.

The fee reimbursement scheme started in late 80 's by undivided Andhra Pradesh government as a social initiative to improve literacy and employability derailed over a period of time due to mushrooming of institutions resulting in unprecedented intake of students' resulting in ballooning budgets with poor outcomes forcing education department to introduce stringent controls.

Internet on the other hand has penetrated young and students' community with the advent of social media. According to the Internet and Mobile Association of
India (IAMAI), around $66 \%$ of the 180 million internet users in major cities frequently access social media out of which $33 \%$ are college students' (Livemint, 2016). Further, it is reported that in 2020, the number of Facebook users in India is expected to reach 262 million, up from 194 million in 2017; majority of them comprising students' (Statista.com, 2018). In recent years, it is found that many students' are pursuing management courses and are simultaneously working in organization's affecting class attendance. The above information throws up challenges to institutions to sustain interest in students' to attend classes.

\section{Literature Survey}

Performance of students' in academics is an important outcome that is tracked to evaluate various inputs which inter alia include qualification of faculty and their experience, pedagogy, institution reputation, effectiveness of governments reimbursement scheme, socio-economic conditions of students', parental educational background etc. From student's perspective, parameters that need to be considered would be his/her commitment towards studies through factors like dedication, regularattendance, assignment completion in time etc. Extensive research has been done using the above variables to correlate to exam results and also to identify the factors that impact the academic performance.

It may be noted that the stakeholders involved in any eco-system want to acquit themselves successfully for the efforts invested over a period of time. The university/institution wants to sustain their reputation through excellent results, faculty want to feel proud of their efforts through students' academic achievements, government want the fee reimbursement scheme to produce long term socio-economic benefits envisaged in the education plan, parents look for economic wellbeing of their children through gainful employment and students' on the other hand, being the focus of attention of all, require to achieve excellent grades to justify the objectives of all the stakeholders.

Major study done by Gajghat et al. (2017) on review of 85 papers and articles revealed that there is a defined effect of number of independent factors on 
the performance of students'. About 48 independent factors and 5 dependent factors were analyzed in the said paper. The findings of Zubair et al. (2013) revealed that age, father/guardian's social economic status and daily study hours significantly contribute to the academic performance of students'. Hijazi and Naqvi (2006) research found that a student's performance in examination was associated with his attitude towards attendance in classes, time allocation for studies, parents' level of income etc. Adeni et al. (2013) study found a strong positive relationship between student's attendance and academic performance. Jayanthi et al. (2014) research showed that factors such as gender and co-curricular activities affected students' academic scores apart from some other common factors. Park and Kerr (1990) study demonstrated that lack of attendance could statistically explain why a student received a lower grade, such as, 'D' rather than higher grades in a specific class. The statistical tests undertaken found that regular class attendance was a significant determinant in reducing a student's chance of receiving lower grades.

The relation of academic performance with various independent factors seems to be quite common at different education levels and with specific courses. Farooq et al. (2011) found that girls perform better than the male students' in Mathematics and English subjects at school level in Pakistan. The results also revealed that socio-economic status and parents' education have a significant effect on students' overall academic performance. Paisey and Paisey (2003) in Scotland and Schmulian and Coetzee (2011) in South Africa both found a clear positive relationship between class attendance and subsequent academic performance in accounting module. Isa and Abdullah (2009) survey results showed existence of a positive relationship between attendance and final results of management accounting subject but found no evidence of a cause and effect relationship between both. In a similar manner, study by Guleker and Keci (2014) at Albania higher education institutions also revealed a correlation between attendance and performance in two civil engineering subjects with no cause and effect relationship. The findings of Caviglia-Harris (2006) showed that student GPA is the most significant and consistent predictor of performance in economics subject and on the contrary, revealed that attendance policy was found to have minimal impact on student achievement. The findings of Romer (1993) showed that the difference in performance between a student who attends regularly and one who attends sporadically is almost a grade higher. Further, surprisingly, the findings from the study of Mlambo (2011) showed that gender, age, learning preferences, and entry qualifications did not cause any significant variation in the academic performance of students' in biochemistry course at University of West Indies.

The study undertaken by the author attempts to confine the variables to three, namely-gender, class attendance and family income to understand their influence on the results in terms of SGPA. Accordingly, Table 1 provides a list of authors and the independent variables which they have correlated with dependent variable, student performance in terms of SGPA and total marks obtained in the semester.

\section{Objective of the Study}

The objective of the study is to find the variables correlating with students' academic performance and the predictors that influence the academic performance.

Table 1. Independent Variables of Gender, Class Attendance and Family Income correlated with Academic Performance (Dependent Variable) by various Authors

\begin{tabular}{|c|c|c|c|c|c|}
\hline Variable & Authors & Variable & Authors & Variable & Authors \\
\hline Gender & $\begin{array}{l}\text { M. Garkaz et al. (2011), } \\
\text { Zakaria et al. (2011), } \\
\text { Mutairi (2011), Zhang et } \\
\text { al. (2004) }\end{array}$ & $\begin{array}{l}\text { Class } \\
\text { Attendance }\end{array}$ & $\begin{array}{l}\text { Sibandi et al. (2015), Erdem (2013), Bennett } \\
\text { and. Yalams (2013), Saleem and Qureshi } \\
\text { (2011), Aden et al. (2013), Steenkamp et al. } \\
\text { (2009), Marburger (2006), Devadoss and } \\
\text { Foltz (1996). }\end{array}$ & $\begin{array}{l}\text { Family } \\
\text { Income }\end{array}$ & $\begin{array}{l}\text { Tesfay and Zekiros (2015), } \\
\text { Muhidin (2016), Ali et al. } \\
\text { (2013), Saleem \& Qureshi } \\
\text { (2011), Daniyal et al. (2011) }\end{array}$ \\
\hline
\end{tabular}

Source: Collated from research article by Radheshyam H. Gajghat, Chandrahas C. Handa, Rakesh L. Himte, Factors Influencing Academic Performance of the Students' at University Level Exam: A Literature Review, International Journal of Research in Engineering and Technology, 2017. 


\section{Hypotheses}

I.H1: There is no correlation between gender and academic performance

II.H2: There is no correlation between parental income and academic performance

III.H3: There is no correlation between class attendance and academic performance

IV.H4: Gender, parental income, and class attendance are predictors of a student's academic performance.

\section{Methodology}

The sample size consists of 93 students' of MBA II Semester class. The data is collected from records and as such is secondary in nature. Statistical tools like correlation technique and regression analysis have been used to interpret and arrive at the relationships.

\section{Limitations}

The sample size is 93 and the data is from one semester from one management college. Only three variables gender, parental income, attendance are considered. Other variables could be considered to identify important correlations and understand the underlying factors for improving academic performance.

\section{Results and Discussions}

The correlations between variables and academic performance are determined at $99 \%$ significance level.
The Pearson correlation coefficient was found to be reasonably strong with positive significance between class attendance and academic performance $(\mathrm{r}=.588)$ and moderate but significant correlation between gender and academic performance $(\mathrm{r}=.353)$. However, correlation between parent's income and academic performance was found to be insignificant (Table 2).

Hence, as per the analysis, the null hypothesis H1, that there is no correlation between gender and academic performance is rejected. Similarly, the third null hypothesis $\mathrm{H} 3$, that there is no correlation between class attendance and academic performance is rejected. However, null hypothesis $\mathrm{H} 2$ that there is no correlation between parental income and academic performance accepted.

Also, regression analysis was conducted with gender, parent's income and attendance as independent variables with SGPA obtained in the semester as a dependent variable. Preliminary analysis was done to ensure that there was no violation of assumptions pertaining to linearity, normality and multicollinearty (Durbin-Watson score $=2.048$ ). The multiple regression equation was calculated [(F3, $89)=17.956, P=.001]$ with an $\mathrm{R}^{2}$ of .377 indicating that the independent variables, taken as a set, account for $38 \%$ of the variance in SGPA obtained by the students'. Please see model summary at Table 3 . The Anova details at Table 4 confirm that the model is suitable to conduct the regression analysis at .001 significance level.

Table 2. Correlations

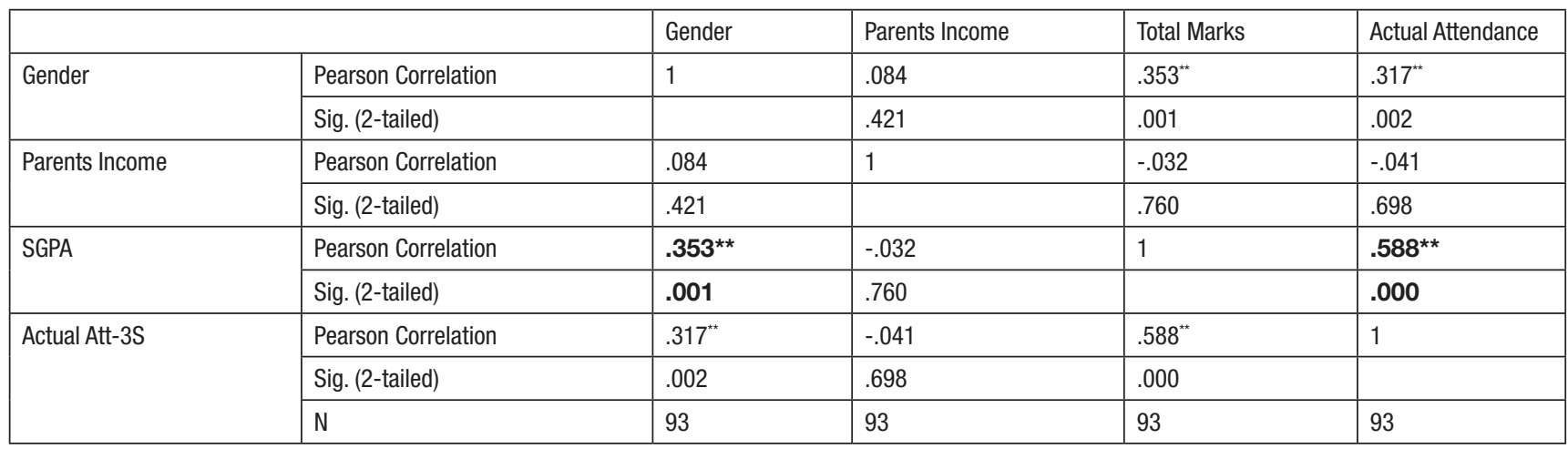

\footnotetext{
**. Correlation is significant at the 0.01 level (2-tailed).
} 
Table 3. Model Summary ${ }^{\mathrm{b}}$

\begin{tabular}{|c|c|c|c|c|c|c|c|c|c|c|}
\hline \multirow[t]{2}{*}{ Model } & \multirow[t]{2}{*}{$\mathrm{R}$} & \multirow[t]{2}{*}{ R Square } & \multirow{2}{*}{$\begin{array}{l}\text { Adjusted R } \\
\text { Square }\end{array}$} & \multirow{2}{*}{$\begin{array}{l}\text { Std. Error of the } \\
\text { Estimate }\end{array}$} & \multicolumn{5}{|l|}{ Change Statistics } & \multirow[t]{2}{*}{ Durbin-Watson } \\
\hline & & & & & R Square Change & F Change & df1 & df2 & Sig. F Change & \\
\hline 1 & $.614^{\mathrm{a}}$ & .377 & .356 & 9.255 & .377 & 17.956 & 3 & 89 & .000 & 2.048 \\
\hline
\end{tabular}

a. Predictors: (Constant), Actual Attendance, Parents Income, Gender

b. Dependent Variable: SGPA

Table 4. ANOVA $^{\mathrm{a}}$

\begin{tabular}{|l|l|l|l|l|l|l|}
\hline \multicolumn{2}{|l|}{ Model } & Sum of Squares & Df & Mean Square & F & Sig. \\
\hline \multirow{4}{*}{1} & Regression & 4613.910 & 3 & 1537.970 & 17.956 & $.000^{b}$ \\
\cline { 2 - 7 } & Residual & 7622.886 & 89 & 85.650 & & \\
\cline { 2 - 7 } & Total & 12236.796 & 92 & & & \\
\hline
\end{tabular}

a. Dependent Variable: SGPA

b. Predictors: (Constant), Actual Attendance, Parents Income, Gender

Table 5. Coefficients ${ }^{\mathrm{a}}$

\begin{tabular}{|c|c|c|c|c|c|c|}
\hline \multicolumn{2}{|c|}{ Model } & \multicolumn{2}{|c|}{ Unstandardized Coefficients } & \multirow{2}{*}{$\begin{array}{l}\text { Standardized Coefficients } \\
\text { Beta }\end{array}$} & \multirow[t]{2}{*}{$t$} & \multirow[t]{2}{*}{ Sig. } \\
\hline & & B & Std. Error & & & \\
\hline \multirow[t]{3}{*}{1} & (Constant) & 29.735 & 2.627 & & 11.320 & .000 \\
\hline & Parents Income & -.233 & .739 & -.027 & -.315 & .753 \\
\hline & Actual Attendance & .207 & .035 & .527 & 5.961 & .000 \\
\hline
\end{tabular}

a. Dependent Variable: SGPA

According to coefficients from Table 5 it is possible to predict the SGPA (academic performance) of the student which is equal to $29.735+4.392 \times$ (Gender) + $0.207 \times$ (Attendance) wherein gender is designated as Male $=0$, Female $=1$ and attendance is in percentage. It shows that a student SGPA increased by 4.392 and 0.207 respectively with each unit change in the independent variables. Both gender and attendance were found to be significant predictors, whereas, parent's income was found to be an insignificant predictor, thus, meeting hypothesis H4 to a large extent.

\section{Conclusion}

Lectures at management institutions go a long way in making the students' learn and assimilate various theories, models, frameworks, Indices, ratios and evaluation methods which would help them in understanding and facing the challenges of corporate world. Most of them cannot be understood by reading text books and all-in-one books. Students' get to learn by practicing and by attempting various exercises and assignments in the college. Hence, regular attendance would improve students' academic performance which in turn could help them to excel in their careers. Also, it can be concluded from the study that academic performance is also dependent on the gender of the student which confirms other studies that academic performance of female students' is better than male students'. Better academic performance would result in better placement opportunities which are ultimately the stake holders endeavor.

\section{Suggestions}

Based on the findings, the following suggestions are proposed which would go a long way in rectifying the problems and improving the SGPA scores in management courses.

a. Minimum class attendance of $75 \%$ by a student should be strictly implemented by institutions and university for appearing in internal and external exams.

b. The monitoring of attendance should be done daily through bio-metric attendance in each class, though difficult, but should be attempted assiduously. 
c. Fee reimbursement must be linked to $75 \%$ attendance with an average $B$ grade score (grade point $=8$ and percentage of marks in the range of 60-69) in each semester.

d. With the above in place state government should release the fee reimbursement amounts regularly for the ecosystem to run successfully.

e. Apart from gender, parental income and attendance, other variables like impact of social media, parents' education level, impact of fee reimbursement, social background, interest of the student in the course and various subjects, competence of the faculty etc. should be considered for further research to understand their individual impact on academic performance of the student.

\section{Bibliography}

Aden, A. A., Yahye, Z. A., \& Dahir, A. M. (2013). The Effect of Student's Attendance on Academic Performance: A Case Study at Simad University Mogadishu, Part-II: Educational and Management Sciences. SAVAP International. Available at: www.savap.org.pk.

Ali, S., Haider, Z., Munir, F., Khan, H., \& Ahmed, A. (2013). Factors Contributing to the Students' Academic Performance: A Case Study of Islamia University SubCampus. American Journal of Educational Research, 1(8), 283-9. https://doi.org/10.12691/education-1-8-3

Caviglia-Harris, J. L., (2006). Attendance and Achievement in Economics: Investigating the Impact of Attendance Policies and Absentee Rates on Student Performance. Journal of Economics and Finance Education. 4(2). Available at: https://www.economics-finance.org/jefe/ econ/Caviglia-Harrispaper.pdf.

Farooq, M.S, Chaudhry, A. H., Shafiq, M., \& Berhanu, G. (2011). Factors Affecting Students' Quality of Academic Performance: A Case of Secondary School Level. Journal of Quality and Technology Management, VII(II), 01-14.

Gajghat, R. H., Handa, C. C., \& Himte, R. L. (2017). Factors Influencing Academic Performance of the
Students' at University Level Exam: A Literature Review. International Journal of Research in Engineering and Technology. 8(4), 447-452.

Guleker, R., \& Keci, J. (2014). The Effect of Attendance on Academic Performance. Mediterranean Journal of Social Sciences, 5(23).

Hijazi, S. T., Naqvi, S. M. M. R. (2006). Factors Affecting Students' Performance A Case of Private Colleges. Bangladesh E-Journal of Sociology. 3(1).

Isa, R. M., \& Abdullah, A. (2009). Students' Attendance at Management Accounting Classes - Reasons and the Effect on Academic Performance. Social and Management Research Journal. 6(1), 87-106.

Jayanthi, S. V., Balakrishnan, S., Ching, A. L. S., Latiff, N. A. A., \& Nasirudeen, A. M. A. (2014). Factors Contributing to Academic Performance of Students' in a Tertiary Institution in Singapore. American Journal of Educational Research.

Livemint,ArticleinBusiness Tabloid.2016.Availableat:https:// www.livemint.com/Politics/FqcL24fK5aQ68qC6KzohJO/ Social-media-in-India.html.

Mlambo, V. (2011). An Analysis of Some Factors Affecting Student Academic Performance in an Introductory Biochemistry Course at the University of the West Indies. Caribbean Teaching Scholar. 1(2), 79-92.

Paisey, C., \& Paisey, N. (2003). Student Attendance in an Accounting Module - Reasons for Non- attendance and the Effect on Academic Performance at a Scottish University. Accounting Education, 13(1), 3-53.

Park, H. K., \& Kerr, P. M. (1990). Determinants of Academic Performance: A Multinomial Logit Approach. The Journal of Economic Education, Spring, 101-11. https:// doi.org/10.2307/1181978 https://doi.org/10.1080/002204 85.1990.10844659

Romer, D. (1993). Do Students' Go to Class? Should They? Journal of Economic Perspectives, 7(3), 167-74.

Schmulian, A., \& Coetzee, S. (2011). Class Absenteeism: Reasons for Non-attendance and the Effect on Academic Performance. Available at: https://repository.up.ac.za/ bitstream/handle/2263/.../Schmulian_Class (2011).pdf

Telangana State Council for Higher Education,(TSCHE), 2018. https://www.tsche.ac.in/. Accessed on 24.05.18. 